\title{
APLIKASI METODE GEOMAGNETIK UNTUK MEMETAKAN SITUS ARKEOLOGI CANDI BADUT MALANG JAWA TIMUR
}

Oleh:

Dina Wulan Kencana ${ }^{1}$, Abdul Basid ${ }^{2}$

\begin{abstract}
ABSTRAK: Arkeologi mengarahkan kajian pada benda-benda peninggalan manusia yang bersifat material dan berhubungan dengan periode paling kuno dalam sejarah umat manusia. Candi badut merupakan peralihan gaya bangunan klasik dari Jawa tengah ke Jawa timur. Awal mulanya hanya berupa gundukan batu, reruntuhan dan tanah. Sehingga diperlukan metode geomagnetic untuk mengetahui struktur dan posisi arkeologi Candi Badut. Pengambilan data dilakukan dengan menggunakan alat magnetometer jenis proton procession magnetometer (PPM) selama satu hari dengan luasan daerah $3025 \mathrm{~m}^{2}$, serta titik pengukuran dibuat dengan jarak $2.5 \mathrm{~m}$ sehingga menghasilkan 418 titik pengukuran. Interpretasi dilakukan secara kualitatif dan kuantitatif dengan menggunakan software surfer 10, magpick dan mag2dc. Hasil penelitian untuk interpretasi kualitatif diperoleh peta kontur anomali residual magnetik memiliki variasi nilai anomali antara $-1000 \mathrm{nT}-800 \mathrm{nT}$. Kemungkinan nilai anomali tinggi diduga adalah candi induk dan pondasi pagar candi yang berada disebelah barat candi induk. Candi induk dan pagar candi terbuat dari batuan andesit. Untuk hasil interpretasi kuantitatif pada irisan AB didapatkan nilai suseptibilitas 0,613 pada batuan candi induk dengan kedalaman $3 \mathrm{~m}$ dan nilai suseptibilitas 0,23 pada pondasi pagar sebelah barat candi induk pada kedalaman $2 \mathrm{~m}$.
\end{abstract}

Kata Kunci : Metode Geomagnetik, Medan Magnet Bumi, Candi Badut

\begin{abstract}
Archeology directs studies on the human heritage objects both its material and relation with the most ancient periods in human history. Badut Temple is a classic transitional style building from Central Java to East Java. In the beginning, it was just a mound of rocks, rubble and ground. So it is needed a geomagnetic method to understand its structure and archaeological position. Data were collected by using proton precession magnetometer (PPM) in one day with $3025 \mathrm{~m}^{2}$ observation area. The 418 point measurements ware determined $2.5 \mathrm{~m}$ in distance. Quantitative and qualitative Interpretations was done by using software surfer 10, magpick and $m a g 2 d c$. The result of this research was obtained residual magnetic anomalies contour map which has anomalous values between $-1000 \mathrm{nT}-800 \mathrm{nT}$ in variation. The main temple and the temple foundation fence located at the west of the main temple was suspected having high anomaly value. These were bricked up from andesite. Quantitative interpretation of $\mathrm{AB}$-slices susceptibility value were obtained 0.613 on the main temple of rock under 3 meters in depth and 0.23 on the foundation of the fence under $2 \mathrm{~m}$ in depth.
\end{abstract}

Keywords: Geomagnetic Method, Earth Magnetic Field, Badut Temple

${ }^{1}$ Mahasiswa Jurusan Fisika, Fakultas Sains dan Teknologi, UIN Maliki Malang. Email: dinawk92@gmail.com

${ }^{2}$ Staf Pengajar pada Jurusan Fisika, Fakultas Sains dan Teknologi, UIN Maliki Malang. Email: faizabasid@yahoo.co.id 


\section{PENDAHULUAN}

Menggali sisa-sisa peninggalan manusia di masa lampau sangatlah penting. Sebagai ilmu bantu sejarah, arkeologi bekerja terkonsentrasi pada horisontal waktu dalam sejarah umat manusia, dimana bukti-bukti tertulis belum ditemukan. Arkeologi bertugas memberi penjelasan terhadap benda-benda peninggalan umat manusia yang sudah terkubur, sehingga benda-benda tersebut kemudian dapat berfungsi sebagai sumber penulisan sejarah.

Metode Geomagnetik juga merupakan salah satu metode dalam geofisika yang sangat sukses untuk prospek-prospek arkeologi, karena metode geomagnetik adalah teknik geofisika pasif yang tergantung pada kontras magnetik suatu benda dengan lingkungan sekitarnya. Faktor-faktor yang signifikan untuk investigasi situs-situs arkeologi adalah magnetisasi dan suseptibilitas magnetik suatu benda. Kebanyakan material arkeologi mengandung partikel magnetik yang akan menyebabkan anomali magnetik sehingga dapat diperlakukan berbeda dengan lingkungan sekitarnya (1).

Selain itu terdapat metode-metode yang tepat dalam pengolahan data Magnetik seperti Gradien horisontal (Horisontal Gradien), sinyal analisis (Analytic Signal), dan turunan vertikal kedua (Second Vertical Derivative) adalah metode yang sukses untuk pengolahan data magnetik. Metode-metode tersebut diantaranya sangat akurat menentukan posisi-posisi anomali, batas-batas anomali dan kedalaman anomali yang ditimbulkan oleh suatu benda. Metode-metode tersebut akan diterapkan pada penelitian ini dan dimodelkan dengan metode forward modelling untuk mencari nilai suseptibilitas dan kedalaman benda penyebab anomali.

Penelitian ini bertujuan untuk menduga struktur bawah permukaan tentang keberadaan dan posisi situs arkeologi Candi Badut dengan menggunakan metode geomagnetik.

Penelitian ini dimulai dengan pengambilan data intensitas magnet, posisi titik pengambilan data, waktu pengambilan data dan ketinggian titik pengambilan data. Pada intensitas magnet dilakukan tiga kali pengambilan data kemudian dirata-rata dan didapat hasil data intensitas medan magnet total. Selanjutnya, dikoreksi Diurnal dan koreksi IGRF. Dari data yang sudah dikoreksi didapat nilai medan magnet anomali total (menggunakan software surfer 10), kemudian dilakukan kontinuasi ke atas, reduksi ke kutub, gradient horisontal, sinyal analitik, vertikal kedua (menggunakan software magpick) dan dimodelkan (menggunakan software $m a g 2 d c$ ) dengan berpaduan pada struktur geologi setempat.

Pengukuran dilakukan dengan metode loop tertutup, yang artinya dalam satu siklus pengukuran, posisi dari titik awal pengukuran dan titik akhirnya sama, titik ini dijadikan sebagai titik acuan (base station). Titik-titik pengukuran dibuat dengan jarak antar titik adalah 2,5 m dengan luas daerah $3025 \mathrm{~m}^{2}$. Data yang diperoleh pada tahap akuisisi data (aquisition data) diambil sebanyak 418 titik pengukuran, dimana datadata tersebut diambil pada tanggal 27 oktober 2013. 


\section{HASIL DAN PEMBAHASAN}

\section{A. Interpretasi Kualitatif}

Posisi geografis daerah penelitian diukur menggunakan peralatan Global Positioning System (GPS). Jumlah data posisi yang diukur adalah 418 titik yang membentang dari posisi geografis $112.5934-112.5987^{\circ} \mathrm{BT}$ dan $7.95736-7.95809^{\circ} \mathrm{LS}$.

Hasil yang didapatkan setelah dikoreksikan IGRF adalah gabungan antara anomali regional dan anomali residual. Sehingga perlu dilakukan pemisahan antara kedua anomali tersebut, karena untuk proses interpretasi hanya dilakukan untuk anomali lokal saja. Untuk memisahkan anomali regional dan anomali residual tersebut maka perlu dilakukan kontinuasi ke atas. Kontinuasi ke atas ini dimaksudkan agar diperoleh pola anomali magnetik regional yang lebih halus (smooth) sehingga anomali residual lebih terlihat dan dapat diketahui benda-benda yang menyebabkan anomali tersebut. Proses kontinuasi ke atas ini dilakukan dengan menggunakan bantuan software Magpick.

Kontinuasi ke atas ini dilakukan pada ketinggian tertentu dengan menghitung data yang seolah-olah diamati pada ketinggian tersebut. Pada pembahasan ini dilakukan kontinuasi ke atas pada ketinggian 100 sampai 500 meter di atas permukaan laut. Hasil kontinuasi ke atas dengan ketinggian 450 meter di atas permukaan laut (gambar 1), anomali regional telah melemah, karena sudah tidak ada pasangan dipole magnetik yang terbentuk pada kontur anomali regional.

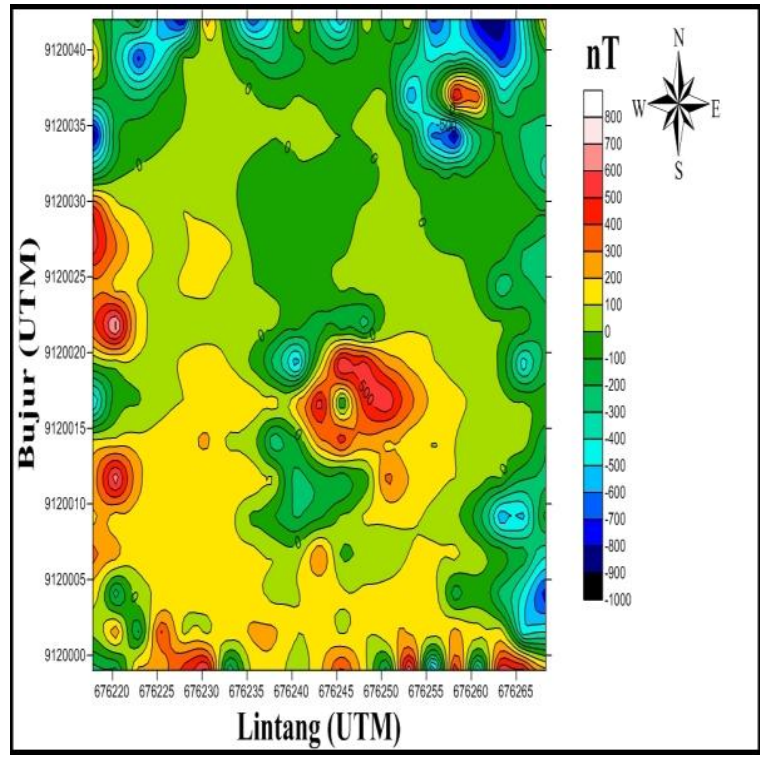

Gambar 1. Kontur Anomali Residual Hasil Kontinuasi ke Atas pada Ketinggian $450 \mathrm{mdpl}$

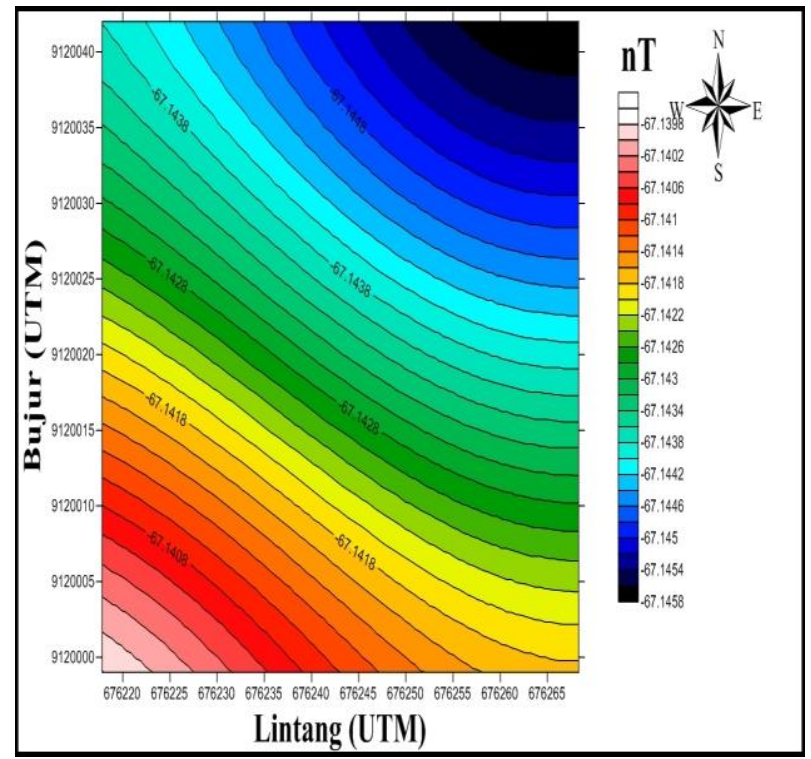

Gambar 2. Kontur Anomali Regional Hasil Kontinuasi ke Atas pada Ketinggian $450 \mathrm{mdpl}$

Gambar 1 dan gambar 2 merupakan hasil dari kontinuasi ke atas dan dapat dijelaskan bahwa variasi nilai anomali Residual magnetik dapat dilihat dari skala warnanya, berkisar antara -1000 nT sampai 800 nT. Anomali Magnetik yang bernilai rendah berkisar -300 nT sampai -1000 nT dan Anomali Magnetik sedang memiliki nilai berkisar -300 nT sampai 200 nT. Anomali Magnetik tinggi yang ditunjukkan yang memiliki nilai lebih dari 200 nT. 
Berdasarkan sisa-sisa bangunannya, candi Badut memiliki pagar keliling dari batu porus dan halamannya berbentuk persegi panjang berukuran $47 \mathrm{~m}$ x $49 \mathrm{~m}$. halaman ini merupakan halaman pusat, sedangkan halaman tengah dan luar belum diketahui. Bangunan candi menghadap ke barat, terbuat dari batu andesit dengan pola pasang tidak berraturan/acak. Keadaan bangunan telah rusak. Dahulu didepan candi terdapat tiga buah bangunan kecil, tetapi pada saat dilaksanakan pemugaran hanya tersisa bagian pondasi bangunan yang terletak di selatan dan utara. Candi ini memiliki bagian yang relatif lengkap yaitu lapik, kaki, tubuh dan atap walaupun bagian tubuh dan atapnya tidak penuh (2).

Gambar 3. Menunjukkan bahwa tanda garis biru merupakan candi induk yang terbuat dari batu andesit dan memiliki nilai anomali magnetik tinggi yaitu 500 nT dengan warna merah. Pada tanda garis merah merupakan pagar daerah candi yang saat ini pagar tersebut terbuat dari besi. Dan untuk tanda garis kuning yang memiliki nilai anomali tinggi merupakan bangunan pos satpam. Bangunan dengan lebar 4 x $4 \mathrm{~m}$ ini mengandung batu bata merah yang dicampur dengan semen sehingga kemungkinan memiliki anomali magnetik tinggi.

Gambar 4. merupakan peta kontur yang sudah ditransformasi ke kutub, dari nilai skala yang didapat nilai anomali magnetik semakin tinggi jika dibandingkan dengan anomali residual magnetik. Hal ini dikarenakan mengubah anomali bipolar menjadi anomali monopolar (satu kutub) dengan cara manghilangkan pengaruh sudut inklinasi magnetik. Nilai anomali Berdasarkan gambar 4. dapat dilihat bahwa nilai anomali magnetiknya berkisar antara -2000 nT sampai $1600 \mathrm{nT}$.

Reduksi ke kutub merupakan teknik pengolahan data yang intensitas magnet total menginduksi medan magnet yang memiliki inklinasi $90^{\circ}$. Metode ini mengubah anomali bipolar menjadi anomali monopolar sehingga metode ini mempermudah untuk menginterpretasikan data magnetik. Reduksi ke kutub mengasumsikan bahwa batuan yang ada pada daerah survei adalah magnetisasi pararel terhadap medan magnet yang ada di bumi. Adapun yang mendasari filter ini adalah adanya perbedaan nilai inklinasi dan deklinasi dari setiap daerah. Sehingga filter ini mencoba untuk mentransformasikan medan magnet dari tempat pengukuran menjadi medan magnet dikutub utara magnetik (3). 


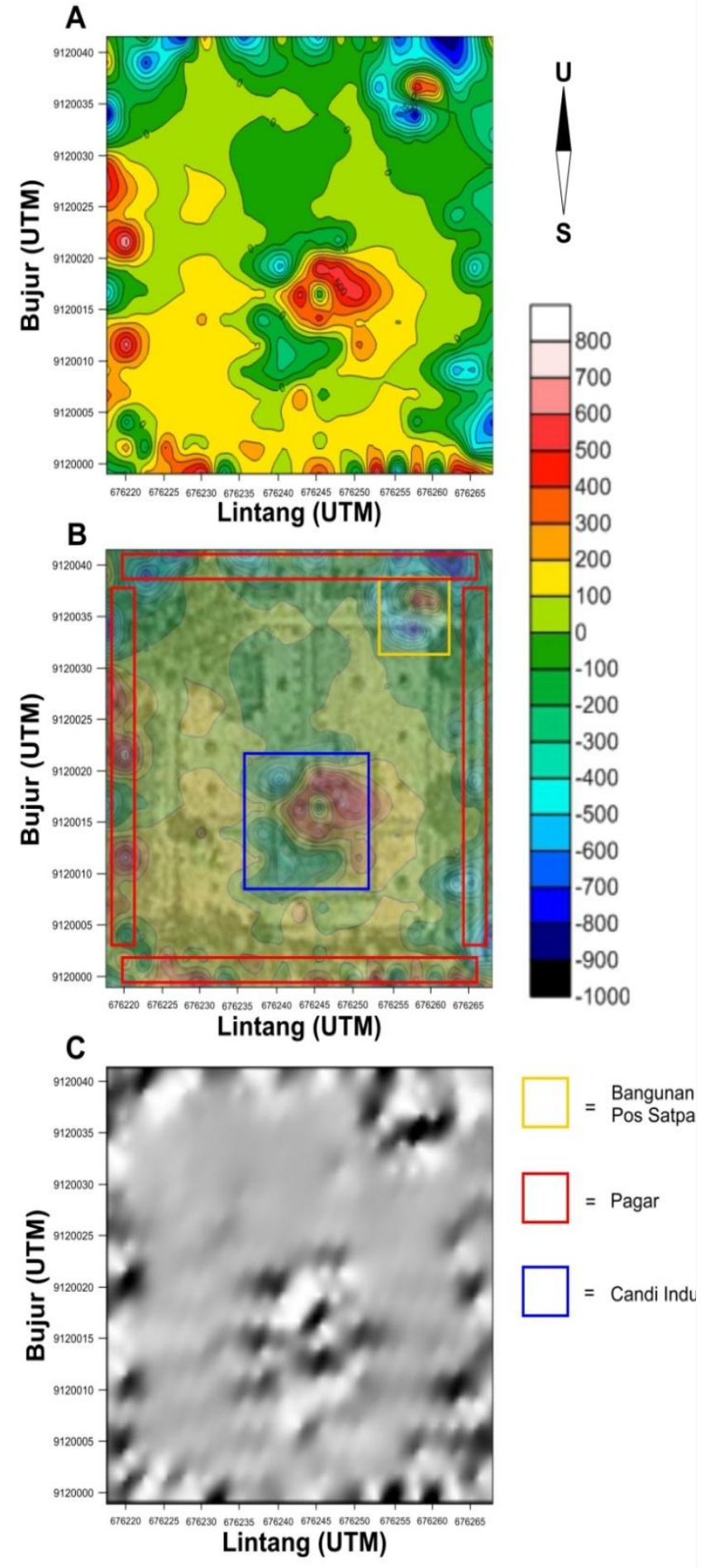

Gambar 3. (A) Kontur Anomali Residual Magnetik dengan interval 100 nT. (B) Kontur Anomali Residual Magnetik dengan Interval kontur $100 \mathrm{nT}$ yang telah di plotkan ke daerah penelitian. (C) Kontur Anomali Residual Magnetik dalam bentuk Relief

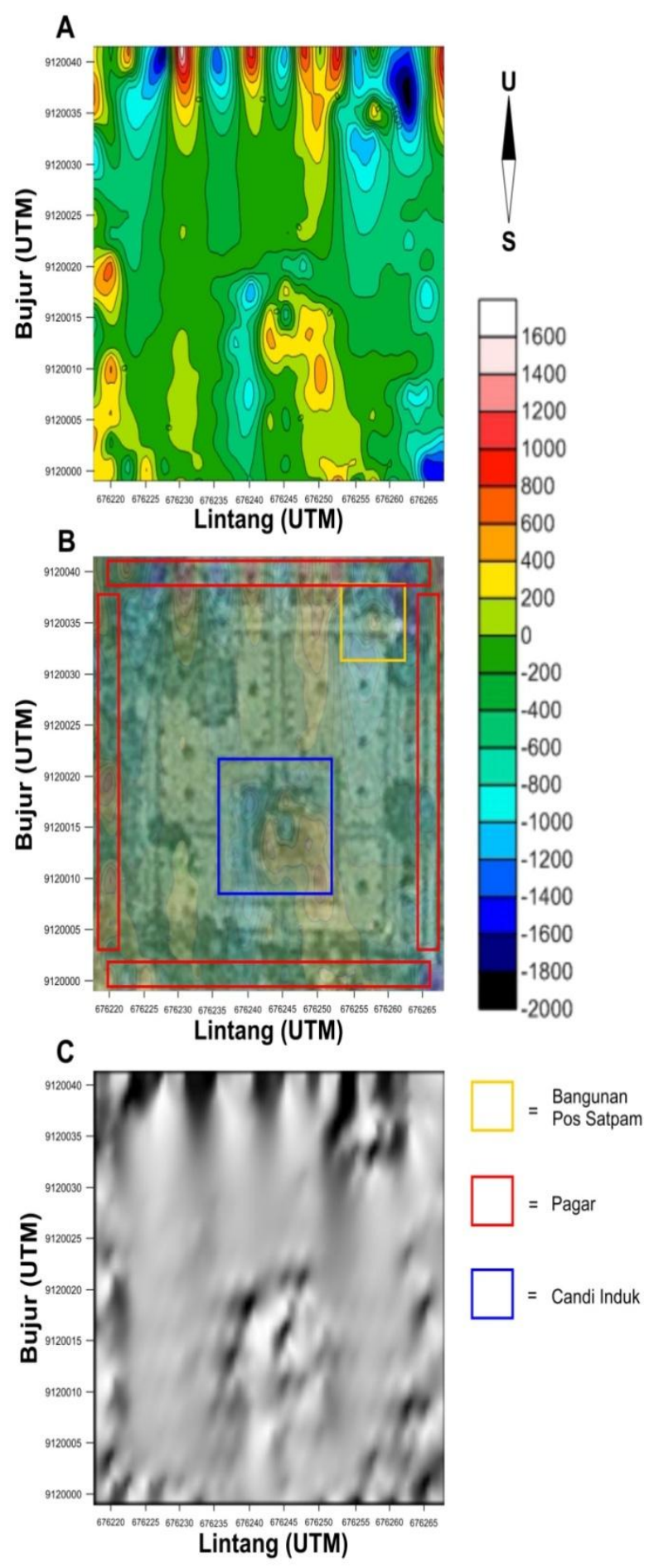

Gambar 4. (A) Kontur hasil reduksi ke kutub dengan interval kontur $100 \mathrm{nT}$.

(B) Kontur hasil reduksi ke kutub dengan interval $100 \mathrm{nT}$ yang telah diplotkan ke daerah penelitian. (C) Kontur hasil reduksi ke kutub dengan bentuk relief. 


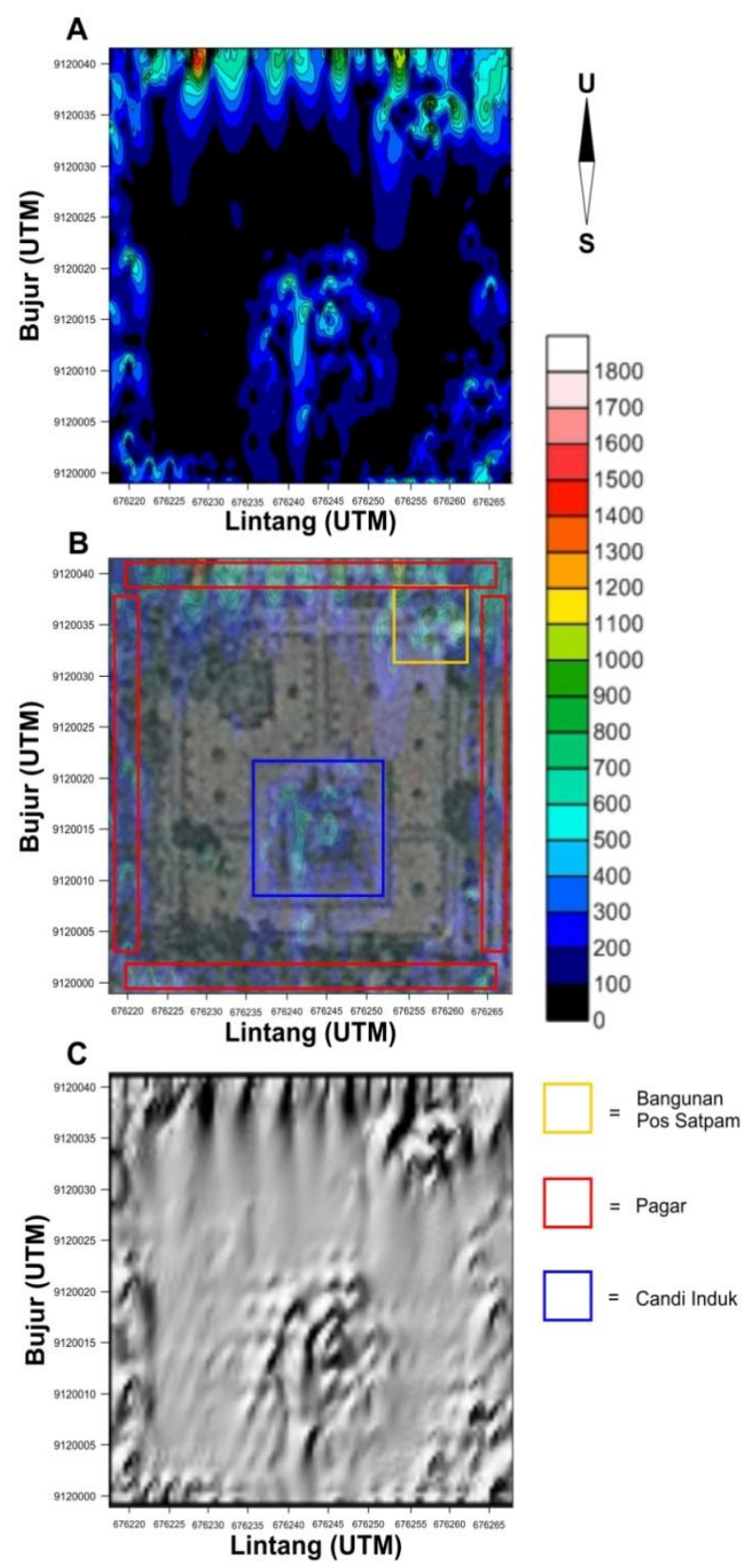

Gambar 5. (A) Kontur hasil gradien horisontal dengan interval kontur 100 nT/m. (B) Kontur hasil gradien horisontal dengan interval kontur $100 \mathrm{nT} / \mathrm{m}$ yang telah diplot ke daerah penelitian. (C) Kontur hasil gradien horisontal dalam bentuk relief.
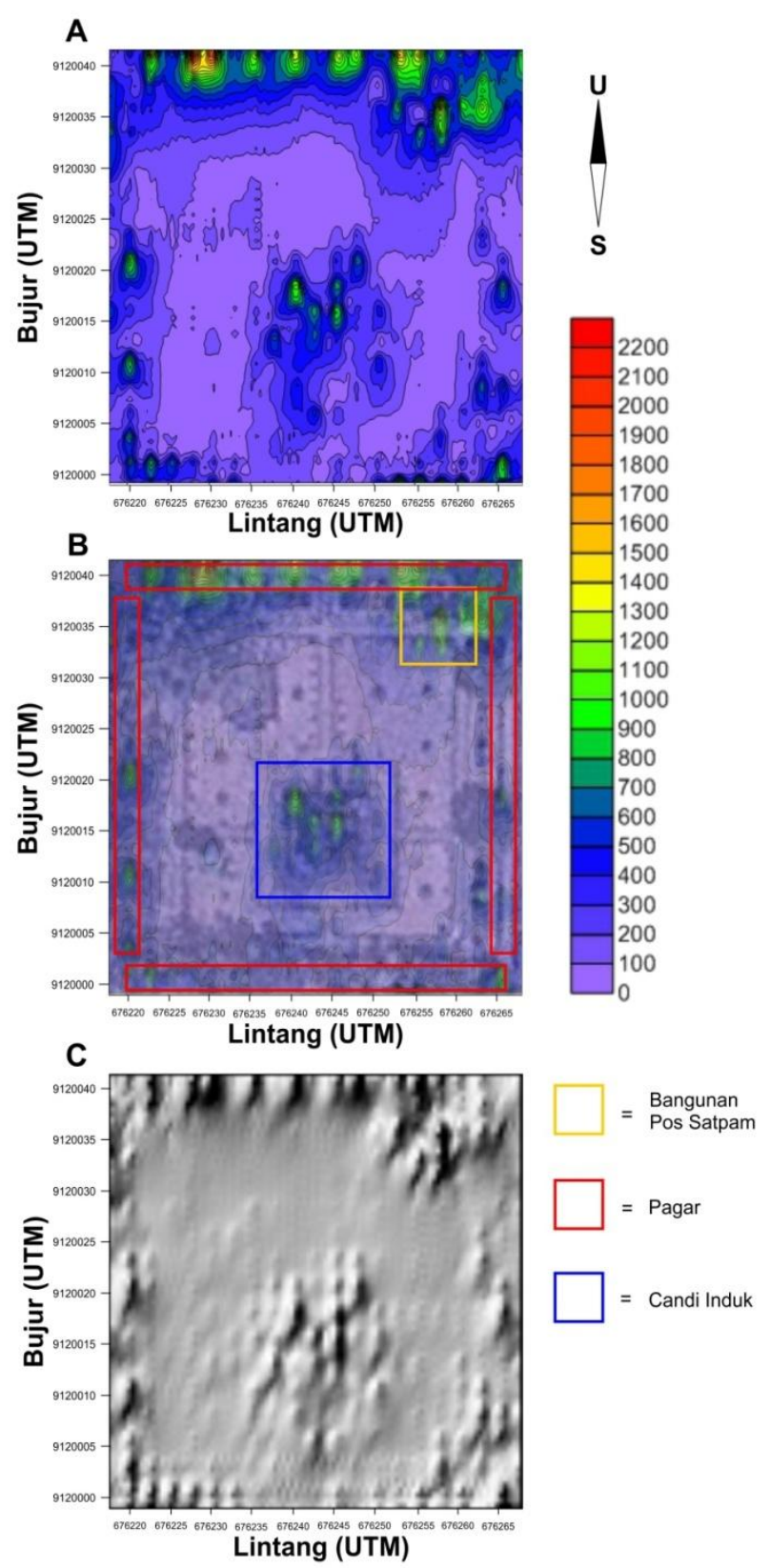

Gambar 6. (A) Kontur hasil Analisis Sinyal dengan interval kontur $100 \mathrm{nT} / \mathrm{m}^{3}$. (B) Kontur hasil Analisis Sinyal dengan interval kontur $100 \mathrm{nT} / \mathrm{m}^{3}$ yang telah diplotkan ke daerah penelitian. (C) Kontur hasil Analisis Sinyal dalam bentuk Relief.

Gambar 5. Merupakan Gradien horisontal dimana sebuah metode yang digunakan untuk menentukan lokasi yang akurat pada kontak vertikal yang terisolasi dari medan magnet yang sudah di reduksi ke kutub. Dengan menggunakan gradien horisontal diharapkan dapat menafsirkan lokasi situs dengan melihat batas-batas tepi dari anomali magnetik (4), yaitu sisa-sisa situs Arkeologi candi Badut.

Metode gradien horisontal menggunakan akar dari kuadrat turunan pertama sehingga awalnya anomali negatif menjadi anomali positif. Hal ini dapat dilihat dari gambar 5 
bahwa anomali dengan kontras magnetik tidak ada yang negatif melainkan semuanya positif. Selanjutnya karena metode ini merupakan turunan pertama maka hasil dari gradien horisontal tidak lagi dalam induksi magnetik (nT) tetapi induksi magnetik per jarak (nT/m). Dari gambar 5 anomali magnetik per jarak berkisar antara $0 \mathrm{nT} / \mathrm{m}$ sampai 1800 $\mathrm{nT} / \mathrm{m}$.

Berdasarkan Gambar 6 dapat dilihat bahwa nilai anomali berbeda dengan nilai metode sebelumnya (gambar 3 dan gambar 4) dimana kontras magnetik tidak ada yang negatif melainkan bernilai positif sama halnya dengan nilai metode gradien horisontal. Hal ini dikarenakan metode analisis sinyal menggunakan akar dari kuadrat turunan pertama sama seperti gradien horisontal, sehingga yang awalnya anomali negatif menjadi anomali positif. Perbedaan antara analisis sinyal dengan gradien horisontal adalah gradien horisontal hanya bergerak dalam domain $\mathrm{x}$ dan $\mathrm{y}$ (lateral) akan tetapi analisis sinyal bergerak dalam domain $\mathrm{x}, \mathrm{y}$, dan $\mathrm{z}$. $\mathrm{z}$ disini dianggap sebagai kedalaman namun sering kali kedalaman tersebut di anggap konstan. Selain itu karena metode ini merupakan turunan pertama maka hasil dari gabungan gradien horisontal dan vertikal tidak lagi dalam induksi magnetik (nT) akan tetapi induksi magnetik per volum $\left(\mathrm{nT} / \mathrm{m}^{3}\right)$. Dari gambar 6 dibawah anomali magnetik per volume berkisar antara $0 \mathrm{nT} / \mathrm{m}^{3}$ sampai $2200 \mathrm{nT} / \mathrm{m}^{3}$.

\section{B. Interpretasi Kuantitatif}

Interpretasi kuantitatif dilakukan pemodelan benda anomali dengan menggunakan 2,5 dimensi dimana metode ini diajukan oleh Talwani dkk (1959). Dalam interpretasi kuantitatif ini menggunakan perangkat lunak mag2dc for windows dimana prinsip kerja dari perangkat lunak ini adalah menyamakan garis kurva anomali sisa yang berbentuk garis putus-putus dengan kurva anomali perhitungan yang membentuk garis tegas. Interpretasi kuantitatif bertujuan untuk menentukan bentuk atau model dan kedalaman benda anomali atau struktur geologi melalui pemodelan matematis.

Dari Gambar 7 merupakan penampang melintang dari irisan garis $\mathrm{AB}$, dapat dianalisa bahwa yang berwana oranye dengan panjang candi 14 meter pada kedalaman 3 meter memiliki nilai suseptibilitas 0,613 diduga sebagai batuan andesit yang tersusun oleh mineral-mineral plagioklas, piroksin, hornblende dan sedikit kuarsa. Dan gambar yang berwarna merah dengan panjang candi 4 meter pada kedalaman 2 meter memiliki nilai suseptibilitas 0,23 yang diduga sebagai pondasi pagar candi yang tertumpuk dari batu andesit dan batu bata. Pendugaan ini didukung oleh hasil interpretasi kualitatif yang memiliki nilai magnetik tinggi pada daerah pondasi pagar. Kemudian untuk gambar segi empat berwarna coklat yang mempunyai nilai suseptibilitas -0,021 dengan panjang candi 3 meter pada kedalaman 1 meter diduga sebagai pondasi pagar yang tersusun dari batu bata dan batu andesit, kemungkinan pondasi pagar tersebut lebih banyak mengandung batu bata sehingga menghasilkan nilai suseptibilitas negatif. 


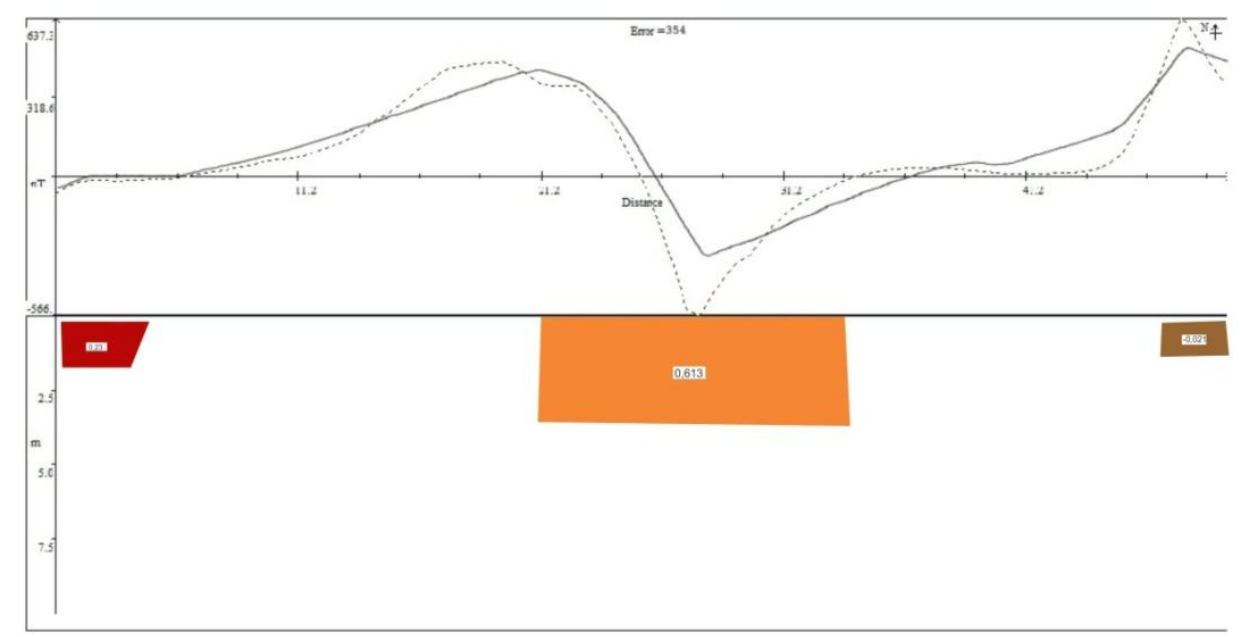

Gambar 7. Model Penampang Anomali Magnetik Irisan AB

\section{KESIMPULAN}

Berdasarkan hasil penelitian geomagnetik dan hasil interpretasi kualitatif dan kuantitatif di daerah candi Badut dapat disimpulkan sebagai berikut :

1. Berdasarkan hasil interpretasi kualitatif pendugaan struktur bawah permukaan situs Arkeologi candi badut Malang dibedakan menjadi tiga yaitu Candi Badut yang mempunyai nilai kontras anomali tinggi berkisar antara 200 nT sampai 800 nT dan ditafsirkan sebagai pondasi candi induk, pondasi pagar dan pondasi bangunan satpam. Untuk candi badut yang mempunyai nilai kontras anomali sedang berkisar antara -400 nT sampai 200 nT ditafsirkan sebagai halaman daerah candi yang terdiri dari batuan beku. Kemudian untuk candi badut yang memiliki nilai kontras anomali rendah berkisar -1000 nT sampai -800 nT ditafsirkan sebagai pepohonan, bangunan pos satpam yang terbuat dari batu bata.

2. Berdasarkan interpretasi kuantitatif pada irisan $A B$ dapat dianalisa bahwa nilai suseptibilitas 0,613 dengan panjang candi 14 meter pada kedalaman 3 meter diduga sebagai pondasi candi induk yang terbuat dari batuan andesit tersusun oleh mineralmineral plagioklas, piroksin, hornblende dan sedikit kuarsa. Untuk suseptibilitas 0,23 dengan panjang candi 4 meter pada kedalaman 2 meter diduga tumpukan batu andesit dan batu bata sebagai pondasi pagar tersembunyi. Kemudian untuk suseptibilitas 0,021 dengan panjang candi 3 meter pada kedalaman 1 meter diduga sebagai pondasi pagar yang tersusun dari batu bata dan batu andesit, kemungkinan pondasi pagar tersebut lebih banyak mengandung batu bata sehingga menghasilkan nilai suseptibilitas negatif.

\section{DAFTAR PUSTAKA}

(1) Schmidt, A. Electrical and Magnetic Methods in Archaeological Prsopection. In. S. Campana and S. Piero (eds) Seeing the Unseen. Geophysical and Landzchape Archaeology: p 67-81. London: Taylor \& Francis; 2009.

(2) Soviyani, Aris. 1996. Candi Badut dan Pemugaran. Malang 
(3) Risdiasari, F. Analisis Zona Potensi Panasbumi Daerah Waesekat, Kabupaten Buru Selatan, Maluku Berdasarkan Data Magnetik. Malang: Jurusan Fisika Universitas Brawijaya; 2010.

(4) Rusli. Aplikasi Metode Geomagnetik Untuk Memetakatan Situs Arkeologi Candi Jagung Probolinggo, Jawa Timur. Malang: Program Studi Fisika. Universitas Brawijaya; 2012. 